\title{
Selenium Dynamics in the Blood of Beef Cows and Calves Fed Diets Supplemented with Organic and Inorganic Selenium Sources and the Effect on Reproduction
}

\author{
P. SLAVÍK ${ }^{1}$, J. ILLEK ${ }^{2}$, R. RAJMON ${ }^{1}$, T. ZELENÝ ${ }^{3}$ F. JÍLEK ${ }^{1}$ \\ ${ }^{1}$ Department of Veterinary Sciences, Czech University of Life Sciences Prague, Czech Republic \\ ${ }^{2}$ Clinic of Ruminant Diseases, University of Veterinary and Pharmaceutical Sciences Brno, Czech Republic \\ ${ }^{3}$ Veterinary Centre, Sušice, Czech Republic
}

Received June 13, 2006

Accepted November 15, 2007

\begin{abstract}
Slavík P., J. Illek, R. Rajmon, T. Zelený, F. Jílek: Selenium Dynamics in the Blood of Beef Cows and Calves Fed Diets Supplemented with Organic and Inorganic Selenium Sources and the Effect on Reproduction. Acta Vet. Brno 2008, 77: 11-15.

The objective of this study was to compare the effects of feed supplementation with sodium selenite or selenized yeast on serum Se levels and reproduction indicators in cattle.

In three beef herds young heifers, cows in late pregnancy, and their calves were randomly grouped by 6 . In Herd 1, the mean Se serum levels were $51.01 \mu \mathrm{g} \cdot \mathrm{l}^{-1}$ in heifers, 32.12 $\mu \mathrm{g} \cdot \mathrm{l}^{1}$ in cows in late pregnancy, and $29.07 \mu \mathrm{g} \cdot \mathrm{l}^{-1}$ in their calves. In Herd 2, $27.42 \mu \mathrm{g} \cdot \mathrm{l}^{-1}$ (heifers), Z22.9 $\mu \mathrm{g} \cdot \mathrm{l}^{-1}$ (late pregnancy), and $23.46 \mu \mathrm{g} \cdot \mathrm{l}^{-1}$ (calves). In Herd 3, $27.07 \mu \mathrm{g} \cdot \mathrm{l}^{-1}$ (heifers), $22 \mu \mathrm{g} \cdot \mathrm{l}^{-1}$ (late pregnant cows), and $31.05 \mu \mathrm{g} \cdot \mathrm{l}^{-1}$ (calves). Over a 6-month period, the animals in Herd 1 were given selenium yeast supplement; in Herd 2 sodium selenite, whereas Herd 3 served as a negative control. Afterwards, a second blood sample was taken. The mean Se serum levels were as follows: Herd 1 (selenium yeast): $90.73 \mu \mathrm{g} \cdot \mathrm{l}^{-1}$ in late pregnant cows $(p<0.01), 57.99 \mu \mathrm{g} \cdot \mathrm{l}^{-1}$ in calves $\left(p<0.01\right.$ ); Herd 2 (sodium selenite): $42.08 \mu \mathrm{g} \cdot \mathrm{l}^{-1}$ (late pregnant cows $p<0.01$ ), $37 \mu \mathrm{g} \cdot \mathrm{l}^{-1}$ (calves $p<$ 0.05 ); Herd 3 (control) $25.77 \mu \mathrm{g} \cdot \mathrm{l}^{-1}$ (late pregnant cows), $32.85 \mu \mathrm{g} \cdot \mathrm{l}^{-1}$ (calves). A significant difference was also observed in the second blood sample taken in both the late pregnant cows and the calves between the Herds 1 and 2 (late pregnant cows $p<0.01$, calves $p<0.01$ ).

No significant differences were demonstrated between the groups. Herds 1 and 2 showed an improvement in their health status, as compared with the previous period, neither in reproduction indicators nor in the weight gain of the calves.
\end{abstract}

Cattle, calves, selenium, beef cattle, yeast, sodium selenite, deficiency

The first reports on the occurrence of selenium deficiencies in cattle in Czechoslovakia and their consequences for health were reported more than 30 years ago (Kursa 1969).

The occurrence of selenium deficiency is associated with low Se concentrations in the soils. This corresponds to the Se levels in fodder crops grown on such soils. Animals fed fresh fodder for only a part of the year, without being regularly given mineral supplements, usually suffer from selenium deficiency (Heningway 2003).

Selenium performs many functions in the body such as affecting sperm motility and development, immunity function (improvement of the bactericidal activity of neutrophile granulocytes, increased antibody production), and affecting reproduction and fertility (occurrence of retained placenta) as well (Underwood and Suttle 1999; Olson et al. 1999; Stanton et al. 2000).

Selenium diffuses the placental barrier and influences the intrauterine and post partum development of the calf (Illek et al. 2002, Enjalbert et al. 2004). Se is also released into colostrum at an increased rate (Pavlata et al. 2004).

The objective of this study was to determine the effect of organic selenium supplementation (such as selenium yeast) on its serum concentration in animals, the influence on their health condition and on selected reproduction indicators in comparison to an inorganic form (such as sodium selenite).

Address for correspondence:

MVDr. Petr Slavík, Ph.D.

Czech University of Life Sciences Prague

Department of Veterinary Sciences

Kamýcká 129, Prague 6, CZ 16521 Czech Republic
Phone: +420224382948

E-mail: slavik.pe@seznam.cz

http://www.vfu.cz/acta-vet/actavet.htm 


\section{Materials and Methods}

Animals included in this study were selected from 3 beef cattle herds. The average altitude of the farms was $450 \mathrm{~m}$. In the summer, animals grazed in a pasture, and during our monitoring they had grain meal at a ration of ca $1 \mathrm{~kg}$ available per animal per day. In the winter they were fed hay and grass silage, and Herd 3 was sometimes fed corn silage.

Samples of the winter diet were collected, i.e. of hay, and grass silage for each herd, and average selenium contents were determined.

After preliminary screening, three herds were chosen for the study, with all herds showing pronounced Se deficiencies and impaired health status. However, frequent or mass occurrences of signs typical of deficiency of some trace elements were not observed.

The breeds selected were as follows: Herd 1 - Piemontaise (22 animals), Herd 2 - beef Simmental (48 animals), Herd 3 - Hereford ( 88 animals) (Table 2). In the spring months when the herds were subjected to performance control and veterinary procedures, blood samples were taken. In each herd under study, three groups of six animals were formed, the animals being chosen at random. The first group included cows in late pregnancy that were due to deliver very soon; the second group included non-pregnant heifers. Blood samples were collected from the calves born to the experimental cows at an average age of 3 weeks ( $+/-5$ days). A total of 54 animals were monitored.

Samples of pasture forage were taken by the mixed sample method from five partial samples. This mixed sample showed mean Se contents of $0.1 \mathrm{mg} \cdot \mathrm{kg}^{-1} \mathrm{DM}$ for Herd $1,0.093 \mathrm{mg} \cdot \mathrm{kg}^{-1} \mathrm{DM}$ for Herd 2, and 0.088 $\mathrm{mg} \cdot \mathrm{kg}^{-1} \mathrm{DM}$ for Herd 3 .

Afterwards, mineral premixes containing Se were provided. The mean Se dose was $1 \mathrm{mg}$ per head per day. The mineral premix was mixed into the grain meal. Herd 1 received an organic Se source (selenium yeast product Sel-Plex 50, Alltech, Nicholasville, KY), Herd 2 an inorganic Se source (sodium selenite), and Herd 3 received a placebo. Their health status was monitored. After 6 months, blood samples were again taken from the cows that became pregnant again in the meantime and the same calves. The animals in all the herds had free access to the mineral lick BIOXANON ${ }^{\circledR}(20 \mathrm{mg}$ Se in an inorganic form per $1 \mathrm{~kg}$ of lick), and all were given the vitamin supplement VITAMIX S8 - BIOFAKTORY (30 mg inorganic Se $\cdot \mathrm{kg}^{-1}$ mineral supplement). The mean daily intake of this mineral mixture was $10 \mathrm{~g}$ per head per day. Blood was withdrawn from the coccygeal vein, in calves from the jugular vein, using the $\mathrm{HEMOS}^{\circledR}$ system. Mineralization of the samples was performed by using microwave technology. The selenium content was determined from serum and pasture by the hydrid method, using the atomic absorption spectrophotometer (HG-AAS) as described by Sturman (1985). For selenium status evaluation, the reference range of $<70 \mu \mathrm{g} \cdot \mathrm{l}^{-1}$ deficit (Stowe and Herdt 1992) was used. According to the NRC (National Research Council) standards, the diet for beef cattle should contain $0.3 \mathrm{mg} \mathrm{Se} \cdot \mathrm{kg}^{-1} \mathrm{DM}$ (NRC 2001).

The results were processed using Microsoft Excel. The mean (x), standard deviation (SD) was calculated; minimum (Min.) and maximum (Max.) values were determined, and in some cases t-test was performed.

Three months after the calving period had ended, ultrasound pregnancy detection was performed in the three herds under observation. Their health condition was monitored, and the weight of calves 120 days after parturition was taken. This is shown in Table 2, and the results are compared with the results from the previous year. The breeding technology was not changed during the monitoring period.

\section{Results and Discussion}

At the beginning of the monitoring, the mean serum Se concentration for all the animals $(\mathrm{n}=54)$ was $\overline{\mathrm{x}}=30.6 \mu \mathrm{g} \cdot \mathrm{l}^{-1}$, i.e., $35.1 \mu \mathrm{g} \cdot \mathrm{l}^{-1}$ in heifers, $26.36 \mu \mathrm{g} \cdot \mathrm{l}^{-1}$ in late pregnant cows, and $27.86 \mu \mathrm{g} \cdot \mathrm{l}^{-1}$ in their calves. The initial values from different herds are shown in Table 1. Herd 1 showed somewhat higher values, but the selenium status was still not satisfactory. At the Clinic of Ruminant Diseases, the reference range of Stowe and Herdt (1992) was used. According to their research, levels below $70 \mu \mathrm{g} \cdot \mathrm{l}^{-1}$ indicate Se deficiency. However, this reference range was intended for dairy cattle. On the contrary, Gerrloff (1992) regarded only values lower than $40 \mu \mathrm{g} \cdot \mathrm{l}^{-1}$ as deficient.

Different initial Se levels in Herd 1 compared to the other herds are also worth mentioning. The results of feedstuff analyses showed that the above values were far below the standard ones for beef cattle $\left(0.3 \mathrm{mg} \cdot \mathrm{kg}^{-1} \mathrm{DM}\right)$. However, in Herd 1 the content of Se was relatively higher.

Table 1 shows the values measured in the same groups of animals after six months of mineral supplementation.

In the present study, a significant increase in Se levels, as compared with the initial ones, was observed in Herd 1 (selenium yeast; pregnant cows $p<0.01$, calves $p<0.01$ ), and in Herd 2 (sodium selenite; pregnant cows $p<0.01$, calves $p<0.05$ ). In Herd 3 no significant differences were found. 
Table 1. Serum Se levels in the groups under study and six months later

\begin{tabular}{|c|c|c|c|c|c|c|c|c|c|c|c|c|c|}
\hline \multicolumn{2}{|r|}{ Herds } & \multicolumn{4}{|c|}{1} & \multicolumn{4}{|c|}{2} & \multicolumn{4}{|c|}{3} \\
\hline & & $x$ & SD & $\min$ & $\max$ & $\mathrm{x}$ & SD & $\min$ & $\max$ & $\mathrm{x}$ & SD & $\min$ & $\max$ \\
\hline \multirow{2}{*}{$\begin{array}{c}\text { Preg. } \\
\text { cows }\end{array}$} & 0 month & 34.12 & 7.32 & 22.42 & 43.74 & 22.9 & 4.99 & 15.43 & 31.34 & 22.8 & 4.8 & 13.49 & 29.57 \\
\hline & 6 months later & 90.73 & 24.08 & 73.4 & 95.9 & 42.08 & 11.33 & 22.66 & 55.06 & 25.77 & 7.08 & 15.12 & 34.3 \\
\hline \multicolumn{2}{|c|}{$T$-test $\left(P^{\text {a }}\right)$} & \multicolumn{4}{|c|}{$* *$} & \multicolumn{4}{|c|}{$*$} & \\
\hline \multicolumn{2}{|c|}{$T$-test $\left(P^{\mathrm{b}}\right)$} & & & & \multicolumn{2}{|c|}{$* *$} & & & \multicolumn{5}{|c|}{$* *$} \\
\hline \multirow{2}{*}{ Calves } & 0 month & 29.07 & 8.5 & 14.71 & 41.4 & 23.46 & 14.37 & 9.24 & 45.47 & 31.05 & 13.8 & 16.45 & 59.12 \\
\hline & 6 months later & 57.99 & 15.6 & 45.99 & 70.09 & 37 & 10 & 45.99 & 49.35 & 32.85 & 13.16 & 17.49 & 50.8 \\
\hline \multicolumn{2}{|c|}{$T$-test $\left(P^{c}\right)$} & \multicolumn{4}{|c|}{$* *$} & \multicolumn{4}{|c|}{ * } & \multicolumn{4}{|c|}{ - } \\
\hline \multicolumn{2}{|c|}{$T$-test $\left(P^{d}\right)$} & & & & \multicolumn{2}{|c|}{$* *$} & & & \multicolumn{2}{|c|}{$* *$} & & & \\
\hline Heifers & 0 month & 51.01 & 12.36 & 37.43 & 69.81 & 27.42 & 3.84 & 19.13 & 30.12 & 27.07 & 3.5 & 24.8 & 35 \\
\hline
\end{tabular}

* - significant difference $(P<0.05)$

** - highly significant difference $(P<0.01)$

$P^{\text {a }}-t$-test in group of pregnant cows between intake in month 0 and 6

$P^{\mathrm{b}}-t$-test in group of pregnant cows supplemented by organic and inorganic forms of Se after 6 months

$P^{\mathrm{c}}-t$-test in group of calves between intake in month 0 and 6

$P^{\mathrm{d}}-t$-test in group of calves supplemented by organic and inorganic forms of Se after 6 months

There was a significant difference $(p<0.01)$ in the second blood analysis between the pregnant cows in both Herd 1 (seleno-yeast) and Herd 2 (sodium selenite). Se serum levels were also higher in the calves whose mothers had been fed selenium yeast, as compared with the calves from the cows fed sodium selenite $(p<0.01)$. This corresponds to the results obtained by Illek et al. (2002) and Gunter et al. (2003). In Herd 3, no significant differences between the blood samples analysed were found.

All the newborn calves received sufficient amounts of colostrum on time. In Herds 1 and 2 , no significant differences between the calves and their mothers were demonstrated in the first blood analysis. The same conclusion was drawn by Pavlata et al. (2004). In Herd 3 , however, a significant difference $(p<0.05)$ between the newborn calves $\left(\overline{\mathrm{x}}=31.05 \mu \mathrm{g} \cdot \mathrm{l}^{-1}\right)$ and their mothers $\left(\overline{\mathrm{x}}=22 \mu \mathrm{g} \cdot \mathrm{l}^{-1}\right)$ was observed. In this herd, the plasma Se levels in the mothers were very low.

The Se levels in calves that did not receive mineral supplements remained unchanged between birth $\left(31.5 \mu \mathrm{g} \cdot \mathrm{l}^{-1}\right)$ and the second blood analysis after 6 months $\left(32.85 \mu \mathrm{g} \cdot \mathrm{l}^{-1}\right)$, which is contradictory to the results obtained by Serdaru (2004), who reported higher Se levels post partum (due to Se intake via colostrum, and subsequent decline in Se levels in calves 60 days after birth).

Gunter etal. (2003) did not find any differences either in the health status or in reproduction indicators between the groups of cows fed different Se sources. There were no differences found in the mortality and viability of calves. They reported only significant differences in serum Se levels between the groups. In the present study, no significant differences in weight gain between the groups of calves were found. Table 2 shows a non-significant increase in gain in the groups that were supplemented with both organic and inorganic forms of Se. In all the herds under study, mating was natural. Within 3 months from the end of the calving period, no differences in the conception rate between the groups of cows were found. The effect of different Se sources on fertility and reproduction indicators was also questioned by Olson et al. (1999). On the contrary, Stanton et al. (2000) reported that cows receiving organically bound trace elements showed a higher conception rate and a shorter interval between calving and conception. However, in their study dairy cows were used. Concerning body mass gains, there was success in demonstrating only nonsignificant increase compared to the year 2004. This increase, however, was also present in the control group and probably has no connection with supplementation. 
Table 2. Reproduction and health indicators in single herds in years 2004 and 2005

\begin{tabular}{|c|c|c|c|c|c|c|}
\hline Herds & \multicolumn{2}{|c|}{1} & \multicolumn{2}{|c|}{2} & \multicolumn{2}{|c|}{3} \\
\hline Years & 2004 & 2005 & 2004 & 2005 & 2004 & 2005 \\
\hline Number of animals in herd & 22 & 22 & 48 & 48 & 88 & 88 \\
\hline Number of cows in herd & 14 & 14 & 30 & 30 & 62 & 62 \\
\hline Parturient weight $(\mathrm{kg})$ of calves $(\mathrm{x})$ & 29.8 & 39.1 & 36.6 & 36.1 & 30.3 & 30.6 \\
\hline$t$-test $(P)$ & \multicolumn{2}{|c|}{ - } & \multicolumn{2}{|c|}{ - } & \multicolumn{2}{|c|}{-} \\
\hline Weight $(\mathrm{kg}) 120$ days pp (x) & 125.6 & 129.1 & 156.5 & 165.6 & 141.5 & 161.3 \\
\hline$t$-test $(P)$ & \multicolumn{2}{|l|}{-} & \multicolumn{2}{|c|}{-} & \multicolumn{2}{|c|}{-} \\
\hline Weight $(\mathrm{kg}) 210$ days pp (x) & 219.3 & 215 & 255 & 264 & 256.1 & 264.1 \\
\hline$t$-test $(P)$ & \multicolumn{2}{|c|}{-} & \multicolumn{2}{|c|}{-} & \multicolumn{2}{|c|}{-} \\
\hline Loss of calves - number of animals & 3 & 2 & 9 & 2 & 9 & 10 \\
\hline Number of pregnant cows & 10 & 13 & 40 & 46 & 81 & 79 \\
\hline Retained placenta - number of animals & 4 & 0 & 10 & 3 & 12 & 10 \\
\hline Mastitis - number of animals & 3 & 0 & 4 & 1 & 6 & 8 \\
\hline
\end{tabular}

In Herds 1 and 2, a lower occurrence of mastitis than in the previous period was observed, as well as fewer cases of retained placenta and lower calf losses.

Organic forms of selenium (for example selenium yeast) reliably ensure the saturation of animals in spite of their severe initial deficiency. In both supplemented groups there was improvement in pregnancy and a decrease in the occurrence of health problems compared to the previous year. Regarding health condition, there was no evidence of any difference between the groups fed organic and inorganic selenium.

\section{Dynamika koncentrace selenu v krvi krav a telat masného skotu při dotaci organické a anorganické formy selenu a vliv na reprodukční ukazatele zvířat}

Cílem studie bylo porovnat efekt suplementace seleničitanu sodného a kvasinkové formy selenu na jeho hodnoty v krevním séru a reprodukční ukazatele u masných plemen skotu. Ve třech chovech masného skotu byly náhodně sestaveny vždy skupiny po šesti kusech, jednalo se o mladé jalovice, vysokobřezí krávy a jejich telata. V chovu č. 1 byla průměrná koncentrace Se v krevním séru jalovic 51,01 $\mu \mathrm{g} \cdot \mathrm{l}^{-1}$, vysokobřezích krav 32,12 $\mu \mathrm{g} \cdot \mathrm{l}^{-1}$ a jejich telat $29,07 \mu \mathrm{g} \cdot \mathrm{l}^{-1}$ Chov č. 2 jalovice $27,42 \mu \mathrm{g} \cdot \mathrm{l}^{-1}$, vysokobřezí krávy $22,9 \mu \mathrm{g} \cdot \mathrm{l}^{-1}$ a jejich telata $23,46 \mu \mathrm{g} \cdot \mathrm{l}^{-1}$. Chov č. 3 jalovice $27,07 \mu \mathrm{g} \cdot \mathrm{l}^{-1}$, vysokobřezí krávy $22 \mu \mathrm{g} \cdot \mathrm{l}^{-1}$ a jejich telata $31,05 \mu \mathrm{g} \cdot \mathrm{l}^{-1}$. Následujících šest měsíců byl zvíratům v chovu č. 1 podáván selén ve formě seleno-yeast v chovu č. 2 ve formě seleničitanu sodného a chov č. 3 byl negativní kontrola. Pak byl proveden druhý odběr krve. V chovu č. 1 (seleno-yeast) březí krávy $90,73 \mu \mathrm{g} \cdot \mathrm{l}^{-1}$, telata 57,99 $\mu \mathrm{g} \cdot \mathrm{l}^{-1}$, chov č. 2 (seleničitan sodný) březí krávy 42,08 $\mu \mathrm{g} \cdot \mathrm{l}^{-1}$, telata $37 \mu \mathrm{g} \cdot \mathrm{l}^{-1}$. A chov č. 3 (bez zvláštní dotace Se) březí krávy $25,77 \mu \mathrm{g} \cdot \mathrm{l}^{-1}$, a telata $32,85 \mu \mathrm{g} \cdot \mathrm{l}^{-1}$. T-test prokázal vysoce statisticky významný rozdíl mezi prvním a druhým odběrem v chovech č. 1 (skupiny březích $\operatorname{krav} p<0,01$, telata $p<0,01$ ) a č. 2. (skupiny březích $\operatorname{krav} p<0,01$, telata $p<0,05)$ Statisticky významný rozdíl je i mezi druhým odběrem u obou kategorií mezi stády č. 1 a č. 2. (březí krávy $p<0,01$, telata $p<0,01$ ). V chovu č. 3 statisticky významný rozdíl mezi jednotlivými odběry nebyl prokázán. Statisticky významný rozdíl nebyl prokázán v reprodukčních ukazatelích ani v př́růstcích telat mezi žádnou skupinou. $\mathrm{V}$ chovech č. 1 a č. 2 ubylo mastitid, zadržených lůžek, snížila se nemocnost a mortalita telat (oproti minulým obdobím). Studie prokázala, že při řešení deficience Se u masného skotu je jednoznačně lepší použít jeho organické formy, které mnohem spolehlivěji a rychleji zvýší jeho hladinu v krvním séru. Naproti tomu jsme nezaznamenali rozdíl mezi organickou a anorganickou skupinou ohledně zdravotního stavu. 


\section{Acknowledgments}

The study was supported by the Ministry of Agriculture of the Czech Republic, grant QF 4005. We thank Mrs. Lois Russell for her linguistic assistance with this manuscript.

\section{References}

ENJALBERT F, LEBRETON P, SALAT O, SCHELCHER F 1999: Effects of pre- or postpartum selenium supplementation on selenium status in beef cows and their calves. J Anim Sci 77: 223-229

GERLOFF BJ 1992: Effect of selenium supplementation on dairy cattle. J Anim Sci 77: 223-229

GUNTER SA, BECK PA, PHILLIPS JM 2003: Effects of supplementary selenium source on the performance and blood measurements in beef cows and their calves. J Anim Sci 81: 856-864

HENINGWAY, RG 2003: The influences of dietary intakes and supplementation with selenium and vitamin E on reproduction diseases and reproductive efficiency in cattle and sheep. Vet Res Commun 27: 159-174

ILLEK J, PAVLATA L, LOKAJOVA E, BECVAR O, MATEJICEK M 2002: Effect of supplementation to gravid heifers on selenium concentration and glutathione peroxidase activity in blood of newborn calves. XXII. World Buiatric Congress Hannover, Proceedings-Abstracts, $74 \mathrm{p}$.

KURSA J 1969: Nutriční svalová degenerace u mladého skotu v distriktu Šumavy. Vet Med 14: 549-559

NRC 2001: Nutrient requirements of domestic animals, Nutrient Requirements of Cattle. $7^{\text {th }}$ ed. National Academy of Sciences, Washington, DC, $263 \mathrm{p}$.

OLSON PA, BRINK DR, HICKOK DT, CARLSON MP, SCHNEIDER NR, ORTMAN K, PEHRSON B 1999: Effect of selenate as a feed supplement to dairy cows in comparison to selenite and selenium yeast. J Anim Sci 77: $3365-3370$

PAVLATA L, PECHOVÁ A, DVOŘÁK R 2004: Microelements in colostrum and blood of cows and their calves during colostral nutrition. Acta Vet Brno 73: 421-429

SERDARU M, VLADESCU L, TOLEA I 2004: Fluorimetric study of the selenium course in the dam-calf relationship. Biol Trace Elem Res 99: 113-121

STANTON TL, WHITTIER JC, GEARY TW, KIMBERLING CV, JOHNSON AB 2000: Effect of trace mineral supplementation on cow-calf performance, reproduction and immune function. Prof Anim Sci 16: 121-127

STOWE HD, HERDT TH 1992: Clinical assessment of selenium status of livestock. J Anim Sci 70: 3928-3933

STURMAN, BT 1985: Development of a continuous-flow hydride and mercury vapour generation accessory for atomic absorption spectrophotometry. Appl Spectrosc 39: 48-56

UNDERWOOD EJ, SUTTLE NF 1999: The trace elements. In.: The Mineral nutrition of livesteck $3^{\text {rd }}$. CABI Publishing Oxon, UK, pp. 125-138 
